\title{
INVESTIGATION OF THE EFFECTS OF FOLIAR FERTILIZERS ON INDUSTRIAL TOMATOES
}

\author{
Attila Hüvely ${ }^{1^{*}}$, Judit Petö ${ }^{1}$ and András Palkovics ${ }^{1}$ \\ ${ }^{1}$ Department of Agricultural Science, Faculty of Horticulture and Rural Development, John von Neumann \\ University, Kecskemét, Hungary \\ https://doi.org/10.47833/2020.2.AGR.029
}

Keywords:
tomato
potassium chloride
Brix\%
sugar content
tomato yield

Article history:

Received 4 May 2020

Revised $\quad 10$ May 2020

Accepted 20 May 2020

\begin{abstract}
Our field experiment was made in 2019 in the study garden of the Faculty of Horticulture and Rural Development. The soil of the experiment was slightly calcareous and alkaline sand with a medium humus content. Three different foliar fertilizer treatments were applied on industrial tomato test plant. Ripening accelerating compounds increased tomato yield. Potassium chloride and Sweet treatments increased yield as well. Water soluble dry matter content was also increased slightly after $\mathrm{KCl}$ and Ethrel treatments.
\end{abstract}

\section{Introduction}

In 2019 we examined the effect of various $\mathrm{KCl}$, Sweet and Ethrel solutions given by foliar feeding on tomato growing. It was the replicate our experiment in 2018. Potassium plays an important role in the coloring and sugar content of the berry. When properly supplied, potassium increases the sugar content of the fruit and makes the color more uniform [1, 2, 4].

A similar conclusion has been reached by other authors, that potassium also affects yield, quality, disease resistance and drought tolerance [6, 7]. In case of small potassium deficiency, yield parameters and drought tolerance are reduced, while the plant does not yet show visible symptoms of potassium deficiency [8, 9, 10].

During the maturation phase, the plant naturally produces ethylene. Ethylene accelerates ripening and discoloration. Depending on the purpose of cultivation, it is possible to reduce or increase the level of ethylene in the plant. In the case of the open-air industrial paradise, artificial raising of the ethylene level seems to have positive effects. For this purpose, ethephon, an active ingredient of Ethrel, can be used as a maturation accelerator [5].

Sweet is a calcium, magnesium, trace element and polysaccharide containing biostimulant. It influences sugar formation and coloration advantageously, and accelerates ripening. The active substances of Sweet are calcium chloride and disodium octaborate-tetrahydrate [11].

In our study we investigated how these products can influence the tomato fruit yield, length of maturation and some quality parameters. Specially we measured the water soluble dry matter (Brix\%) in the berry.

\section{Materials and methods}

The experiment was carried out in the Faculty of Horticulture and Rural Development of John von Neumann University, in 2019.

\footnotetext{
* Corresponding author. Tel.: +36 517-661

E-mail address: huvely.attila@kvk.uni-neumann.hu
} 
The area of the open field experiment in the demonstration garden was 0.01 ha $(10 \times 10 \mathrm{~m})$. The soil of the experiment was slightly calcareous $\left(2.52 \mathrm{~m} / \mathrm{m} \% \mathrm{CaCO}_{3}\right)$ sand with medium humus $(2.40 \mathrm{~m} / \mathrm{m} \%)$ content and slightly alkaline $\mathrm{pH}\left(7.39 \mathrm{pH}_{\mathrm{H} 2 \mathrm{O}}\right)$.

We made eight parallel rows. We used healthy seedlings in good condition. Seedlings were planted in uniform spacing of $1.2 \times 0.25 \mathrm{~m}$.

Our test plant was H1281 hybrid tomato from Heinz Seed. It is an available hybrid currently that is well-proven in Hungarian growing. A short-growing, early-maturing variety.

It is a determined variety for processing. Fruits have $85-100 \mathrm{~g}$ average weight and thick walls, dark red color, high pigment content, and good (4,8 - 5.1) Brix\%.

The applied leaf nutrient treatments were the following:

- No. 1-2 rows: Control

- No. 3-4 rows: $\mathrm{KCl}, 40 \mathrm{~kg} / \mathrm{ha}$

- No. 5-6 rows: Ethrel, $0.2 \%$

- No. 7-8 rows: Sweet, $6.5 \mathrm{l} / \mathrm{ha}$.

The first specific ripening accelerator treatment was sprayed on 05.08 .2019 , at $10 \%$ ripeness of tomato berries and the second was given one week later, at $50 \%$ ripeness of tomato berries. Soil parameters were similar in all groups. Cultivation, usual fertilization, plant protection and irrigation were made in the same way in control and each treatment parcels.

Harvesting was made in the middle august. Tomato fruits were tested in the Soil and Plant Testing Laboratory of the faculty Fresh fruits were sliced and thoroughly mixed, and soluble dry matter content (Brix\%) was measured with laboratory refractometer.

\section{Results}

The yield of the harvested tomato after spraying with $\mathrm{KCl}$ was $10.4 \%$ higher than control parcel. If we used Ethrel the yield had increased for 5.8\%. The highest yield (10.8\%) was obtained after application of Sweet. The effect of different treatments on yield of tomato is shown in Figure 1.

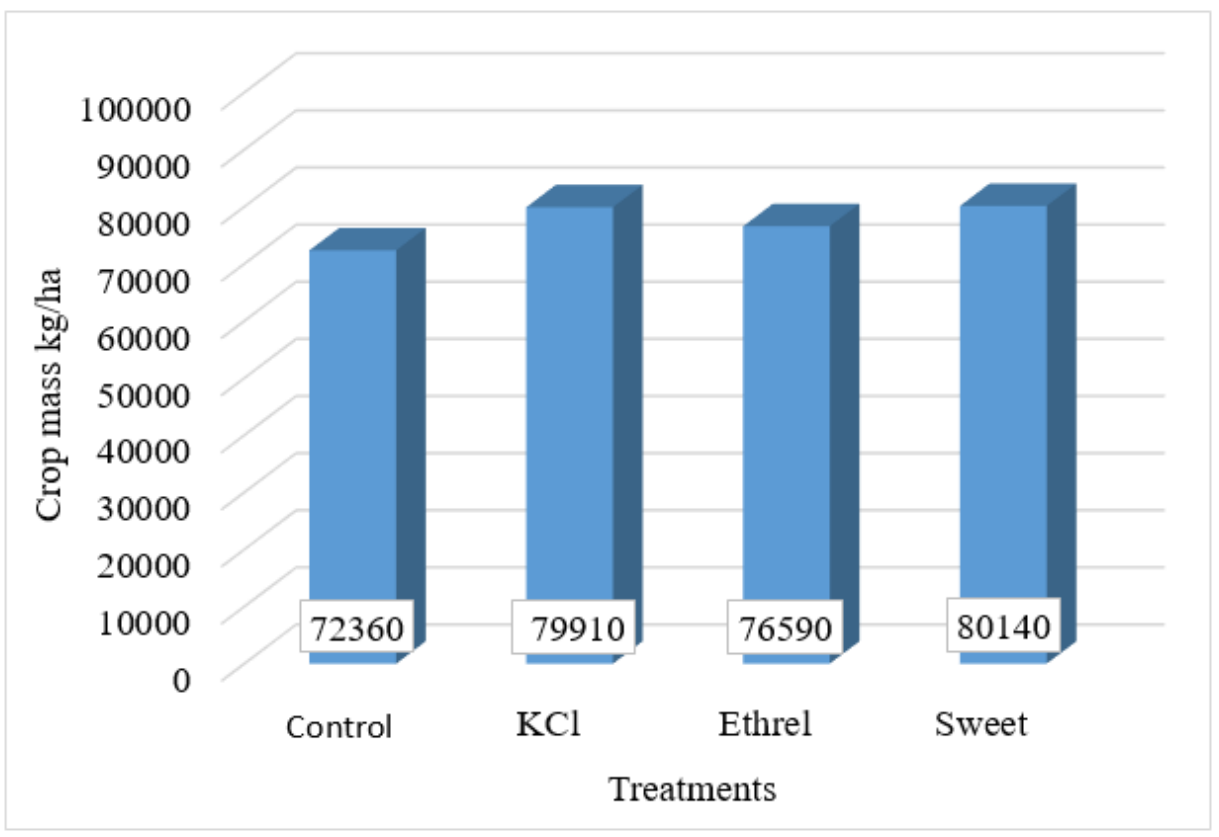

Figure 1. The effect of different treatments on yield of tomato.

Water soluble dry matter had increased in tomato fruit after treatment with $\mathrm{KCl}(0.3 \mathrm{Brix} \%)$ and Ethrel $(0.2 \mathrm{Brix} \%)$ applications. The highest water soluble dry matter content was obtained from $\mathrm{KCl}$ 
and the lowest dry matter content was obtained from Sweet. The effect of different treatments on water soluble dry matter of tomato is given in Figure 2.

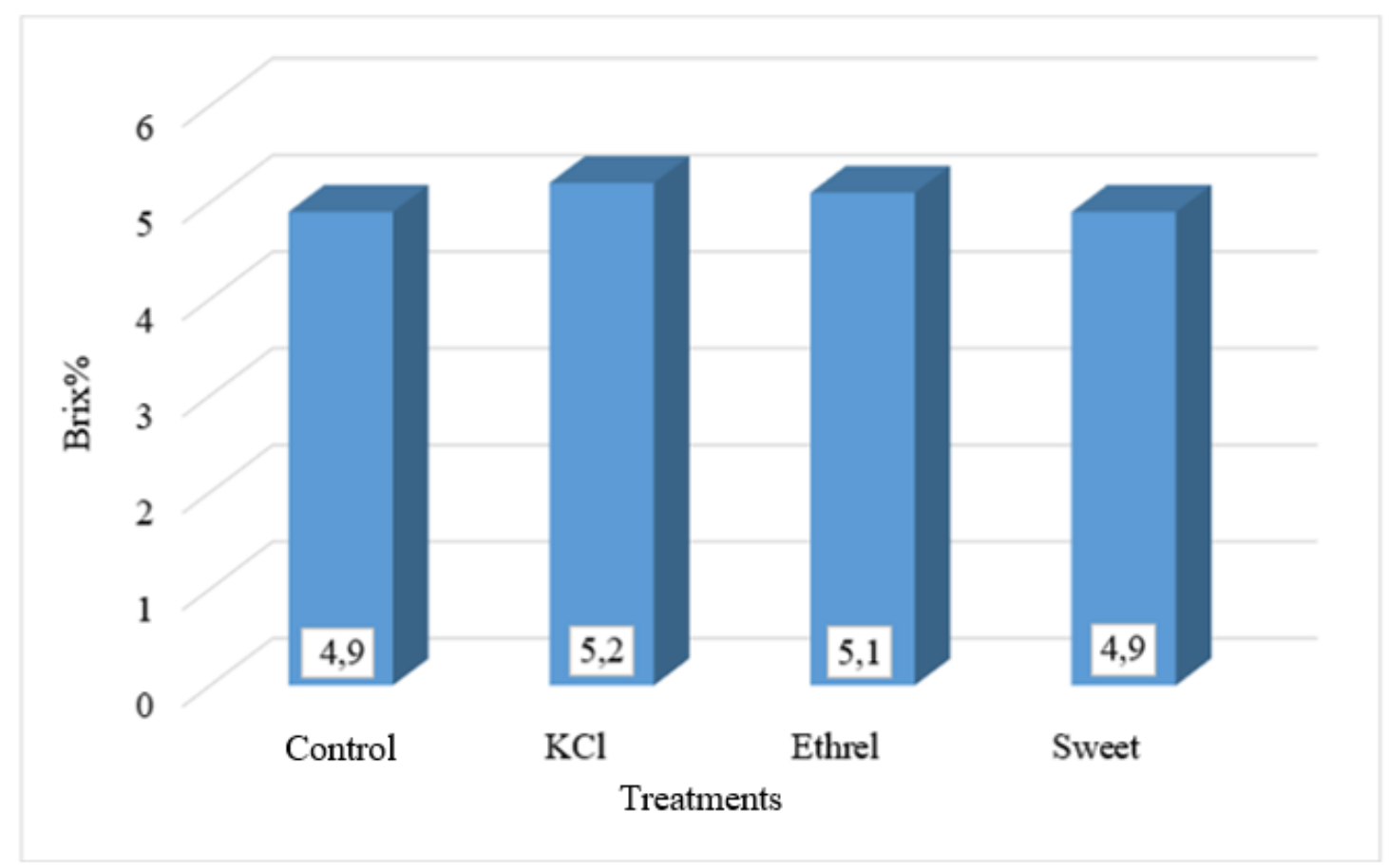

Figure 2. The effect of different treatments on water soluble dry matter of tomato.

The leaf nutrient sprayings had a positive impact of the yield and Brix\%. If we used $\mathrm{KCl}$ and Ethrel we got better results than in control.

\section{Discussion}

In our preliminary study, carried out in 2019 in an open-field trial, we followed the effect of potassium and two biostimulant on tomato growing. During the growing season the nutrient supply was optimal for the plants.

The yield of the harvested tomato increased after all treatments. The highest yield was reached after application of Sweet.

$\mathrm{KCl}$ and Ethrel increased the sugar level by 0.2-0.3 Brix\%, while Sweet made no more difference. The increase is not significant in numerical terms, but it is significant in determining the price of industrial tomatoes. The industrial tomato fruit should have a minimum Brix $\%$ of $5 \%$ at harvesting. In our experiment this value was already reached in $\mathrm{KCl}$ and Ethrel groups.

Like to the findings of other authors and our experiment in 2018 [12], in our case, the sugar content of the crop increased due to the adequate potassium supply [3].

Like to the results of GAWEDA et al. [3], etephon can increase the sugar and dry matter content slightly, compared to the control.

\section{Acknowledgment}

Authors wish to thank for the support of the research carried out in the framework of the EFOP3.6.2-16-2017-00012 „Developing a functional, healthy and safe food product chain model from field to table in a thematic research network". The project is funded by the Hungarian State and the European Union, co-financed by the European Social Fund, and is part of the Széchenyi 2020 program. 


\section{References}

[1] BALÁZS S. (1985): Paradicsomtermesztés. Mezőgazdasági Kiadó, Budapest. pp. 63-91.

[2] BUZÁS I. (szerk.) (1983): A növénytáplálás zsebkönyve. Mezőgazdasági kiadó, Budapest. pp. 36-43.

[3] GAWEDA, M.- JEDRSZCZYK, E.- SKOWERA, B.- JEDRZEJCZAK, R.- SZYMCZYK, K. (2016): The Effect of Application of Ethephon to Processing Tomato Palnts on the Chemical Composition of Fruits. Academic Pres. pp. 485-486.

[4] HARTZ, T.K.- JOHNSTONE, P.R.- FRANCIS, D.M.- MIYAO, E.M. (2005): Processing Tomato Yield and Friut Quality Improved with Potassium Fertigation. HortScience, Vol. 40 No.6. pp.1862-1867

[5] HELYES L. (2000): A paradicsom és termesztése. Mezőgazda Lap- és Könyvkiadó Kft, Budapest. pp. 27-193.

[6] HODOSSI S.- KOVÁCS A.- TERBE I. (2004): Zöldségtermesztés szabadföldön. Mezőgazda Kiadó. Budapest. pp. 129-134.

[7] HORINKA T. (2010): Kertészeti növények komplett tápanyagellátása. Kertészek kis/Nagy Áruháza Kft. pp. 275-285.

[8] SOMOS A. (1971): A paradicsom. Akadémiai Kiadó, Budapest. pp.152-158.

[9] SOMOS A. (1971): A paradicsom. 59-63 pp. In: VIDÉKI L. (1969): A paradicsom minőségét meghatározó néhány tényező. Doktori értekezés, Kecskemét. kézirat p. 148.

[10] SOMOS A. (1983): Zöldségtermesztés. Mezőgazdasági Kiadó, Budapest. p. 219.

[11] https://malagrow.hu/termek/sweet/ [05-30-2019]

[12] HÜVELY, A. - PETÖ, J. - HEGYESI, D. (2019): The impact of different foliar fertilizers on the quantity and nutrient content of industrial tomato. Gradus Vol 6, No 3 (2019) pp. 219-226. 